\title{
A Proposed Railway from the Mediterranean to India
}

\author{
C. E. D. Black Esq.
}

To cite this article: C. E. D. Black Esq. (1911) A Proposed Railway from the Mediterranean to India, Royal United Services Institution. Journal, 55:405, 1409-1428, DOI:

10.1080/03071841109417873

To link to this article: http://dx.doi.org/10.1080/03071841109417873

\section{Published online: 11 Sep 2009.}

Submit your article to this journal ¿

Џ Article views: 8

Q View related articles $\sqsubset$ 


\title{
THE JOURNAL \\ OF THA
}

\section{ROYAL UNITED SERVICE INSTTTUTION}

VoL. LV. NOVEMBER, 1911, No. 405.

[Authors alone are responsibic for the contents of their respective Papers.]

\section{A PROPOSED RAILWAY FROM THE MEDITERRANEAN TO INDIA.}

\author{
By C. E. D. BLACK, EsQ. \\ On Wednesday, October r8th, I9II. \\ The Right Hon. Sir Henry Mortimer Durand, G.C.M.G., \\ K.C.S.I., K.C.I.E., in the Chair.
}

SYNOPSIS OF LECTURE.

Introduction.-The Euphrates Valley Project.-Is an "All Red" Railway to India Possible?-General Alignment of the proposed railway.-The Trans-Arabian Section.-An Arabian Oasis Midway.-The Amir of Jebel Shommer and the Beduins.-Mesopotamia and the Persian Section. -Track of the Railway through Central Persia.-Arrival at the British Frontier of India.-Cost of Railway and Chief Sources of Revenue.The Bagdad Railway.--Summary.-Opinion of Experts.

I am glad to be honoured with an invitation from the Royal United Service Institution to read a paper on the subject of the projected railway from the Mediterranean to India, via Northern Arabia and Southern Persia, as I believe much might be done at once towards furthering this British project, which many consider essential to the security of India.

\section{Iatroduction.}

It is unnecessary to trace the whole history of communications between India and the Mediterranean beyond pointing out that Great Britain has throughout displayed an extraordinary indifference to its importarice. The Suez Canal, as we all know, was built not only with no assistance from England, but actually in the teeth of England's strong opposition encountered at the hands of Lord Palmerston and his Government. And yet England, as everybody knows, has profited far more than any other country from the existence of the Canal, and notwithstanding the recent growth of foreign navies and mercantile YOL. LV. 
marines, 62 per cent. of the aggregate tonnage passing through the Canal in 1910 was British.

In view of this acceleration of the sea transit, it is really astonishing that no serious effort has been made to improve land communication between India and Europe. Russia has built her trans-Siberian railway across the whole vast expanse of the $A$ siatic Continent, from the Urals to the Pacific Ocean, and had she, instead of us, been the mistress of India, we may certainly fairly infer that she would not have refrained from dealing with the far easier task of a railuay to India.

\section{The Eupbrates Valley Project.}

But Great Britain has for forty years shewn a curious disinclination even to consider such a project. In I871-72 public opinion was indeed stirred to the point of an enquiry into the fcasibility of constructing a line from the Mediterranean to the Persian Gulf. A Select Committee of the House of Commons was appointed under the Chairmanship of Sir G. Jenkinson to examine and report upon the whole subject of railway communication between the Mlediterranean, the Black Sea, and the Persian Gulf. Two most interesting volumes of evidence were produced, containing the views of military officers, naval officers, merchants, railway engineers, civilians, and travellers familiar with those regions. The Report unanimously recommended the opening up of communications betueen the British and Turkish Governments for the construction of a railway from the Syrian coast to the Persian Gulf. Sir George Jenkinson and Musurus Pasha, the Turkish Ambassador, acting under the instructions of his Government, entered into full pourparlers and an agreement was arrived at between the two Powers. The chief features of this were the raising of an Ottoman loan, the interest of which was to be guaranteed by England, the provision of the land free for the railway by the Turkish Government, the free carriage of the English mails and the conveyance of British troops to and from India at the same rates as vere to be paid for Turkish troops.

In spite of this agreement nothing came of the project. The fact was, that although improved communications with India were put in the forefront of the scheme, the Euphrates Valley Railway--as it was called-was not a complete project to run a line to the frontier of India. It stopped short half way, at the head of the Persian Gulf, and made no effort to cover the huge remaining gap of 1,500 miles or so to Karachi, at that time the westernmost port and rail-head of India. Although the promoters of the Euphrates Valley Railway made much of an estimated saving of a couple of days in the journey to India, they were content to stop at Basra or Koweit and to leave the eastward prolongation of their line to the gates of India to the chance developments of the future! 
Great Britain and the Persian Gulf.

And this is exactly what the promoters of the Bagdad Railway are doing now, a pretty clear proof that their main object is to facilitate Germany's access to the Persian Gulf more than to improve India's communications with Europe or Egypt. But inasmuch as British Governments have openly declared more than once that England will maintain her supremacy vi el armis in the Persian Gulf, the Turko-German promoters of the Bagdad Railway are face to face $w$ ith this difficulty : that they cannot prolong their line southward of Bagdad, so as to reach the coveted shores of the Persian Gulf without England's assent. England, judging from Sir Edward Grey's-speeches, is not indisposed to grant her assent on certain conditions, and my firm conviction and contention are that a 'Turkish concession for the construction of any projected line from the North End of the Suez Canal at Port Said to Basra, Koweit, and the Persian frontier, at the head of the Persian Gulf, via Akaba, Maan and El Jauf ought to be the price payable to England for her assent.

\section{Is an "All Red" Railway to India Possible?}

The alignment of this projected railway from Egypt to Western India is an effort-partial though it may be-to solve the question of a direct British or "all red" railway route to India, as contrasted with a more roundabout route passing through regions further north, where German, Russian, or other foreign influences are in evidence. It is obvious that if British gold and British influence are being invoked on behalf of a railway to India, common sense and justice, if not self-preservation, demand that such a line should run practically under British control. How is this to be effected, when we bear in mind that the Continent of Europe, with the complications and jealousies of a whole world, intervenes between Iondon and the British sphere in the East?

Fortunately the sea still-lies open to us, and Gibraitar, Malta,.Cyprus, and Egypt form convenient stepping stones en route. Starting from the last of these, i.e., from Port Said, or, rather, from the opposite bank of the Suez Canal, there lies a feasible route eastward to Nushki, which is India's westernmost rail-head at present. This route is the most direct conceivable, as it follows very closely the "great arc" of the $3^{\text {oth }}$ parallel of north latitude, while it offers no insuperable topographical obstacles, the chief difficulties being the bridging of the Shat-elArab, Karun, and the marshy ground at the head of the Gulf and the ascent from the lowlands to the Persian plateau: $W$ ith those exceptions, which pale irito insignificance before such achievements as the bridging of the great. Salt Lake in America or of the gigantic inundation of the Yellow River in China; there are no more than average natural features to be negotiated, considerably less than in the far longer and more difficult Siberian railway. 


\section{General Aligument of the Proposed Railway.}

The railway would actually touch the sea at three points, Port Said, Akaba, and Koweit, and indirectly it would be in communication with the coast at two or three other points in Turkish and Persian territory, to say nothing of its proximity at its eastern terminus to large and important Indian towns. This fact is not only most helpful in the matter of landing stores and supplies during construction of the line, but it will enable several sections to be built simultaneously-a most important factor towards expediting the laying of the line. Very few, if any of the great railways of the world could boast of this advantage. And the same exceptional feature would prove invaluable in case of hostilities and trouble anywhere within touch of the line, as it would enable troops, ammunition, weapons, or stores to be landed at any one of these various points.

\section{The Trans-Arabian Section,}

There are some desert and quasi-desert tracts which would have to be traversed, but the sterile countries of the world have nowhere impeded railway construction, in fact, they have actually facilitated it. Witness the Soudan, Russian Trans-Caspia, Rajputana, West Australia, etc. It is important here to describe the topography, especially of the western half of the projected line, from the Mediterranean, across the north of Arabia to the head of the Persian Gulf, as this is the key of the whole situation. From the northern end of the Suez Canal, the line would run $S . W$. to Akaba at the head of the narrow gulf of the same name, which figures so conspicuously on maps of the Red Sea. So far, it would follow generally the Haj or pilgrim road to Mecca. It might be feasible to run a short branch line to Akaba, which lies on the coast at a much lower level, of course, than the great Arabian plateau. The main line would thus not have to descend and ascend so much steep ground before gaining the plateau. But from thence eastward, to a point equidistant from Basra and Koweit, whither a branch would diverge, the region consists of nothing more formidable than a stony, not sandy, country, averaging throughout about 2,000 feet above sea level (see Charles Huber's map with its numerous heights) and studded here and there with low hills. It is most interesting to note that $\mathrm{Mr}$. Carruthers, one of the most recent travellers in these parts, has within the last eighteen months stated that he came across wells and ruined caravanserais, proving clearly to his mind that the very alignment I am advocating for the railway, is identical with an old caravan route.which centuries ago used to be followed by the traders from Maan to the Persian Gulf. It is indeed no new thing to find the highways of antiquity reviving and materialising into the railways of the present day, but it is very encouraging to note that the feasibility of 
this route is endorsed by the wisdom and experience of past ages. Indeed, Mr. Charles M. Doughty, another well-known Arabian traveller, has written to me, highly approving my proposals. These are his words :- "A railway to India, making us less dependent on the Suez Canal, is truly a pattiolic enterprise, which by way of northern Arabia I have often thought upon, and which I believe, if money could be found for a political investment, to be quite feasible. The entry mastered, the rest is a high plateau without serious difficulty, and everywhere there is water within reasonable distance."

\section{Arabian Oases Midway.}

Mid-way across Arabia there is a most important oasıs, forming an invaluable objective point, half-way house, and resting place for the future railway passengers. It is called E1 Jauf or Djowf and has been visited and reported on by IV. G. Palgrave, Mr. Wilfrid and Lady Anne Blunt, Charles Huber, Baron von Nolde, the Revd. A. Forder, and Captain Butler. All these passed through and stayed at El Jauf. The first-named (Palgrave) speaks with some enthusiasm of its appear. ance, resources, vegetation and fruit, and the liberality and hospitality of the inhabitants. The number of these, according to Mr. Forder, a recent traveller, is 40,000 , and a few miles northeast is another populous oasis called Sekaka. Both of these oases are of great antiquity, and there is evidence that they were more extensive in ancient times than at present. They are a standing refutation of the popular illusion that northern A rabia is sheer desert et praterea nihil. The drainage, judging from the course of the wadys, is north-easterly towards the head of the Gulf. Between El Jauf and Basra there is no regular survey that I know of. I have not come across a record of any European traveller who has ever passed this way, but I am glad to say I possess a native itinerary, showing halting stations and wells, which was furnished to me some years ago hy our Resident in the Persian Gulf. It corroborates the opinion that beyond scarcity of water, which, of course, might be remedied by proper boring appliances, there is no more difficulty in running a railway in N.E. Arabia than has been encountered by the Turkish engineers in constructing the Hejaz railway in Western Arabia. In fact, Mr. Carruthers, the Arabian explorer, has declared that my proposed railway would be easier to construct than the Hejaz railway to the Holy Cities of Islam was, a few years ago.

A glance at the map will enable anyone to realize that the trans-Arabian section is the golden key of the situation we are considering. The trans-Persian line to the Indian frontier is of course essential, and in point of bridging, hill-climbing, and tunnelling, will be found more difficult. But in that country we shall be operating in a region where we have treaty-rights. 
The trans-Arabian route is in the open market, so to speak, and can be secured by anyone if proper measures be promptly taken with (I) the 'Turkish Government (who occupy somewhat, but not exactly, the position of the Suzerain Power) (2) the Amir of Jebel Shommer, the actual ruler of this part of independent Arabia, and (3) the various groups of independent Beduin tribes between the Gulf of A kaba and Basra.

Turkey might probably be squared at the present moment if the concession for the trans-Arabian line were demanded as the price of British consent to the prolongation of the Bagdad Railway to the Gulf.

\section{The Amir of Jebel Shommer and the Beduios.}

The permission of the Beduin Amir and good-will of the tribes en route could be obtained by personal negotiations by an emissary: from London, who might be accompanied by an engineer and mineralogist or geologist. 'The envoy could conclude agreenents, covenanting that for certain subsidies, payable from a stipulated date, the land necessary for the railway with a mile or so on either hand with all mineral and other rights within this zone would be leased or ceded to the company constructing the line. The subsidies would be payable annually or quarterly on the distinct understanding that each tribe was responsible for the security of the section of the line nearest to its usual habitat. Any injury to the line or its employees or robbery committed within the tribal sphere would stop that particular subsidy. I believe this plan is pursued in the case of the telegraph line in Palestine, and is found to work well. The subsidies or allowances would, of course, be settled with the Construction Company after all the preliminary arrangements had been concluded, but their amount would be ascertained by the preliminary survey expedition.

\section{Mesopotamin and the Persian Section.}

I have devoted a good deal of space towards considering the trans-Arabian section, because it presses. But I must explain that the Persian section has been studied with equal care. After the survey expeditions, working from Cairo and Port Said, have covered the whole Arabian and Turkish route via Akabah, Maun, across the Hejaz railway (with which an important junction would be effected) and via El Jauf to Basra, Mahommerah and the Persian frontier, it would be necessary for them to ascend to the Persian plateau. As already explained, this will necessitate crossing the Shat-el-Arab and Karun by swingbridges and traversing the surrounding lowlands, which will be costly, though not excessively so. Here great assistance will be derived from the surveys and other operations of Sir Willinm Willcocks, who has been carrying out a gigantic and 
expensive scheme of reorganization of the ancient irrigation works of Mesopotamia (once the granary of the world) under the orders of the Turkish Government. The Bagdad Railway is sure to act as a useful means of conveyance for the grain and other produce of Mesopotamia to Asia Minor and the intermediate Turkish provinces. But Sir William Willcocks has already said that it will be necessary to have a railway running direct to the Syrian coast as well, to avoid the long roundabout sea-voyage down the Persian Gulf and up the Red Sea and through the Suez Canal into the waters of the Mediterranean. Our railway, though directed to the Egyptian rather than the Syrian coast, will fulfil this requirement, and thus prove most useful to Turkey as well as to England and India. Where the line enters on Persian territory it would pass within a few hours' journey of the principal works of the Anglo-Persian Oil Company, to whose undertaking the railway might prove a valuable feeder.

\section{Track of the Railway through Central Persia.}

Shortly, the Persian section would pass close to Yezd, Shiraz and Kerman, the three chief commercial places of central Persia. For years, I may mention, our Consuls in Persia have been lamenting the backward condition of trade, the absence of roads, and the various difficulties interposed in the way of commerce. A few years ago a special commercial mission was despatched with the approval of Lord Curzon, then Viceroy, from India to Southern Persia, principally with the object of developing the trade with India. A very valuable report, choke-full of practical information was produced, but very little, if anything, was done to carry out the numerous recommendations therein, chiefly because of the disturbed con. ditions of Southern Persia especially. England has intimated to Persia in unmistakably firm language, that unless security of life and property are absolutely restored, England herself will ensure that, with the aid of Indian troops, and this step is now being taken. I have read all recent works on Persia and have had valuable letters from Major Ducat and other Consular Offices there, and there can be no doubt whatever of the enormous incentive to, and development of local trade that a Persian railway, running from the Gulf to the IndoSeistan frontier would bring about. Amongst other things it would lead to the immediate construction of a road and telegraph line from Bunder Abbas, the chief southern port, to Kerman. I happen to know a good deal about this, as three years ago a well-known city company asked me to write a full report with estimates of cost on this scheme, and had it not been for the ensuing Persian troubles, the road and telegraph would have been partly constructed, and, indeed, nearly completed by now. 


\section{Arrival at the British Frontier of India.}

Between Kerman and the British frontier at Seistan-in fact I may say as regards Persia generally-I have received most valuable information and help from Mr. H. R. Sykes, the well-known Persian traveller. I need not reproduce all he says in detail here, but, shortly, it consists of evidence entirely favourable to the railway, as to alignment, topography, physical difficulties, labour and water. Transport, however, is costly, at present; as may be inferred from what I have said above.

We have now arrived at the British frontier, and from thence. to Nushki, the present Indian railhead towards the west, it is quite plain sailing, as a trade route, with post-stations at intervals, has been laid down by the Indian Government for a distance of over 400 miles. I take it, however, they would probably wish to reserve to themselves and their own P.W. Department the actual construction of the railway along this stretch in accordance with the general trend of Indian railway policy of late years.

\section{Necessity of Surrey from Fnd to Fnd.}

The first step towards the accomplishment of the railway is a survey of the route from end to end. It need not, at this stage, be an elaborate survey; it should be more of a reconnaissance survey, but it is essential that some one qualified persontwo would be better-should carry out such a survey, starting from Port Said, crossing the Sinai Peninsula to Akaba, thence working up the slopes of the plateau towards Maan, and thence proceeding eastward to El Jauf. From the latter point to Basra, as I have already mentioned, the region is very little known. I believe that it would be possible to obtain usefuI surveys from the engineers of the Hejaz railway of the western portion of the route, and from Sir William Willcocks in respect of the eastern tracks abutting on Basra. As far as concerns the Turkish territory round the Gulf of Akaba, and as far eastward as the Hejaz railway, this has been leased by the Turkish Government to an influential British syndicate who are most friendly to the project we are considering.

It would be desirable to ascertain from the Amir at El Jauf, his views, frankly, as to the making of a railway through that town; and what compensation, subsidy, or share of the profits he would require. Also his exact relations with the various tribes en route. This information is essential to the undertaking, for El Jauf, as I have said before, is the key of the project. My general idea is for the Beduins to undertake the policing of the line, and for the Amir at El. Jauf to do the same, as regards the territory for which he is responsible, the whole of the 750 miles or so from Akaba to Basra being leased to the Company by the Turkish Government, whose suzerainty, nominal though it be in the interior, must be respected. 


\section{Cost of Railway and Chiel Sourcer of Revenue.}

A very important question is, Can such a railway pay? A line of 2,000 miles in length, costing, so far as one can judge from railways in adjacent regions, about $\notin 6,000$ a mile, would mean a capital expenditure of some $\ell_{12}, 000,000$, and adding $\ell_{3}, 000,000$ for rolling stock, one gets a total of fifteen million sterling, the interest on which, at $3 \frac{1}{2}$ per cent, plus $\frac{1}{2}$ per cent. for sinking fund, would amount to $£ 600,000$ per annum. Would the railway earn this in addition to its working ex. penses? This is, of course, difficult to predict with confidence. The Indian railways, taken collectively, pay 4.81 per cent., and they exploit regions of a very diverse character, varying from sterile tracts, such as those of Rajputana, to well-watered plains teeming with population and culture like those of Bengal. It must be borne in mind, however, that the principal advantages of a railway such as we are considering, do not lie in its purely commercial earnings derived from the productiveness of the country traversed. An end-to-end trunk railway, designed to shorten communications between India and the Mother Country cannot be judged by the considerations and arguments applicable to a line or branch of two or three hundred miles, designed to exploit a limited area, or a remote part of some larger colony. It will be apparent from what has been already said that the through traffic which may fairly be anticipated is of a very extensive and exceptional character. Civil servants on furlough, military officers, and British soldiers, of whom ihere are 34,000 annually passing backwards and forwards, merchants and others interested in the businesses of India and the East, might be reckoned on as only too glad, in the majority of cases, to avail themselves of a means of transit which will save them six entire days, or twelve on the return journey, as the case may be. All these considerations point to a very large passenger traffic. In the case of need arising for the rapid conveyance of troops eastward or westward, the saving of time can hardly be measured by money. Then the pilgrim traffic would be very large, when we bear in mind that there are over 6o millions of Mahommedans in India alone, a large proportion of whom would be only too glad to achieve the great object of their lives and visit the holy places of Islam. Lastly we must take due note of the acceleration of the mails, for it is not conceivable that the public will allow these to travel by any but the speediest means of conveyance, and a saving of six days means much from a business point of view.

\section{The Bagdad Railway.}

Before taking leave of the subject, it is difficult to avoid saying a few words as to the Bagdad Railway. Whether the Bagdad Railway will ever materialize or not, it is impossible to predict : its main professed object, which is to open up and 
develop an enormous expanse of the Turkish Empire, is one with which every friend of civilization must fully sympathize; at the same time it cannot be said to have the same high aims -administrative, political, commercial and defensive-as the Egypto-Indian line. I would even go further, and say that the railway we are specially considering, if regarded only as a link between two of the chief countries under British rule, is an actual Imperial necessity. Still, the construction of a British railway to the East, which would eventually meet the Bagdad line, say, at Basra, might conceivably be viewed in some respects as a rival undertaking.

In reply, one cannot help saying this-that if the aims of the Bagdad Railway are purely pacific and economic (and ample assurances on this head have been often forthcomingi, it is impossible to contend that the two undertakings are in any sense rivals, still less inimical, one to another. They may possibly touch at some point in or near Mesopotamia, but from that point, westward they diverge in utterly different directions, the Bagdad Railway north-west towards Asia Minor, the EgyploArabian line due west towards the Red Sea and Northern Egypt. The former would exploit the Euphrates Valley; the latter, Arabia, Egypt and Sinai, while the huge Syrian desert would intervene between the two, and preclude any overlapping of interests. The Egypto-Indian railway could not be viewed as an unfriendly move against any Power except on the absurd and utterly untenable ground that what tends to strengthen Great Britain's tenure of India is a menace to others.

\section{Summary.}

To sum up. This railway is desirable for various important reasons.

1. It will shorten the journey to India by six whole days, thus reducing the time of transit from England to India to 8 days only, in lieu of 14 or 15 .

2. It will form a valuable alternative route to India and the East generally, in case the Suez Canal were blocked, either through accident or design.

3. For the rapid conveyance of troops from India to the Mediterranean or vice versa the line would be invaluable, and of vital service to the Empire.

4. It would also be highly useful for the expeditious con. veyance of officials, passengers, mails and merchandise to and from India and countries beyond.

5. It would fit in with and prove of great service to the Turkish projects for the irrigation and re-vivification of Mesopotamia.

6. It would supply an important means of access for Mahommadan pilgrims, whether from India or clsewhere, to the holy places of Islam, through junction with the Hejaz railway at Maan. 
7. It is the only line of railway from Europe or the Mediter. ranean to India which would be under British control from end to end.

Having closely studied this question for over twenty years and consulted many of the first naval and military authorities, railway engineers, travellers, diplomatists, and writers conversant with the subject, I am more than ever convinced of the practicability and the desirableness of the undertaking. Every fresh piece of information that has come to $\mathrm{my}$ hand has only confirmed my opinion of the soundness of the project. When a survey of the route from end to end is once carried out we shall be in a strong position to ask the Government to support what I believe to be the greatest Imperial necessity of the present day.

I annex the opinions of some expert authorities.

\section{OPINIONS OF EXPERTS.}

Lieut.fieneral Sir Eowin Colus, G.C.I.E., C.B.

"I have been much struck with the manner in which Mr. Black has laid before us the views and opinions he has formed after long study of this question. ..... It becomes us to discuss the merits and demerits of the project, and, if it is found a leasible one, we as a country slould put our heart and soul into it."

Dr. Cottreall Tere, LI.D. :-

"Certainly it would be a very good thing for India if we could secure the making of this railway. It is the most direct route and the one most free from foreign interference. The investment would be a good one politically."

Mr. II. R. Sykms (Persian traveller) :-

"I agree with the lecturer as to the great importance of securing British control of a line to India. Now that the subject has been raised it ought not to be allowed to drop. The matter should be in. vestigated, and its significance should be brought home to the British public."

Mr. H. F. B. Lумсн, M.P.:-

"We ought to press for detailed and prompt examination of the scheme by experts. I can only express the hope that the matter will be thoroughly threshed out very scon, for, if this is not done, the ground will be cut from under our feet by the construction of the Bagdad railway."

Colonel C. E. Yatr. C.S.I., C.M.G., M.P. :-

"If the scheme is practicable it is to be heartily weicomod. Nothing could be better for us than to have a line in these regions
under our sole controt. earnest."

"I hope it (the project) may be taken up and examined in real 
Sir F. Fryer, K.C.S.I. :-

"The scheme seems in every way a desirable one. I have had some experience of pioneer lines and I have noticed that when the facility is given there generally springs up a considerable amount of local traffic. I will ask you to accord the lectures a hearty vote of thanks, and to give him our best wishes for the line he has advocated being made the subject of prompt enquiry."

Mr. D. Carkuthers (recent Arabian explorer and resident in the country :"For a railway from Egypt to the Persian Gulf no greater hindrances exist than those already overcome by the builders of the Hejaz railway. As a whole the type of country would be easier than that crossed by the Mecca line, and the physical difficulties less severe.

"The objection put forward that the Beduin would prove hostile to the building of the railway is, I think, unfounded. If the SuezBasra line was built, the Beduin who inhabit the region through which the line would pass need not be interfered with in any such way. They would not lose their independence through the buikding of the railway. The Beduin are not unreasoning barbarians, but are quick to recognise a powerful and just Government."

Lieut.-General Sir EDwin Cor.Lns, G.C.1.E., C.B.:-

"I have no doubt there would be a large pilgrim and other native traffic, while the military and strategic advantages are unquestionable. At one time, one difficulty appeared to me to be the safety of the line. But I am assured by men who know the Arab tribes that there would be no difficulty at all if we made up our minds to subsidise them, just as ae do on the N.W. fronticr of India."

Mr. G. H. LISt (formerly Chief Engineer, Indian State Railways) :-

"The proposed Indo-Egyptian railway is certainly the most direct conceivable means of reaching India from the West, and the fact that it would traverse some sterile tracts affords no sort of obstacle, when we consider the railways that have so successfully been built in the Soudan, India, West Australia, and elsewhere. Furthermore, the all-important fact that such a line will shorten the journey to India by five or six days is incontestable cvidence of its value from an Imperial and commercial point of view.".

Among the organs of the Press the Daily Mail, Daily Telegraph, Morning Post, Pioneer (Allahabad), The Civil and Military Gasette (Lahore), Englishman and Times of India have had strongly eulogistic comments on the project. . 


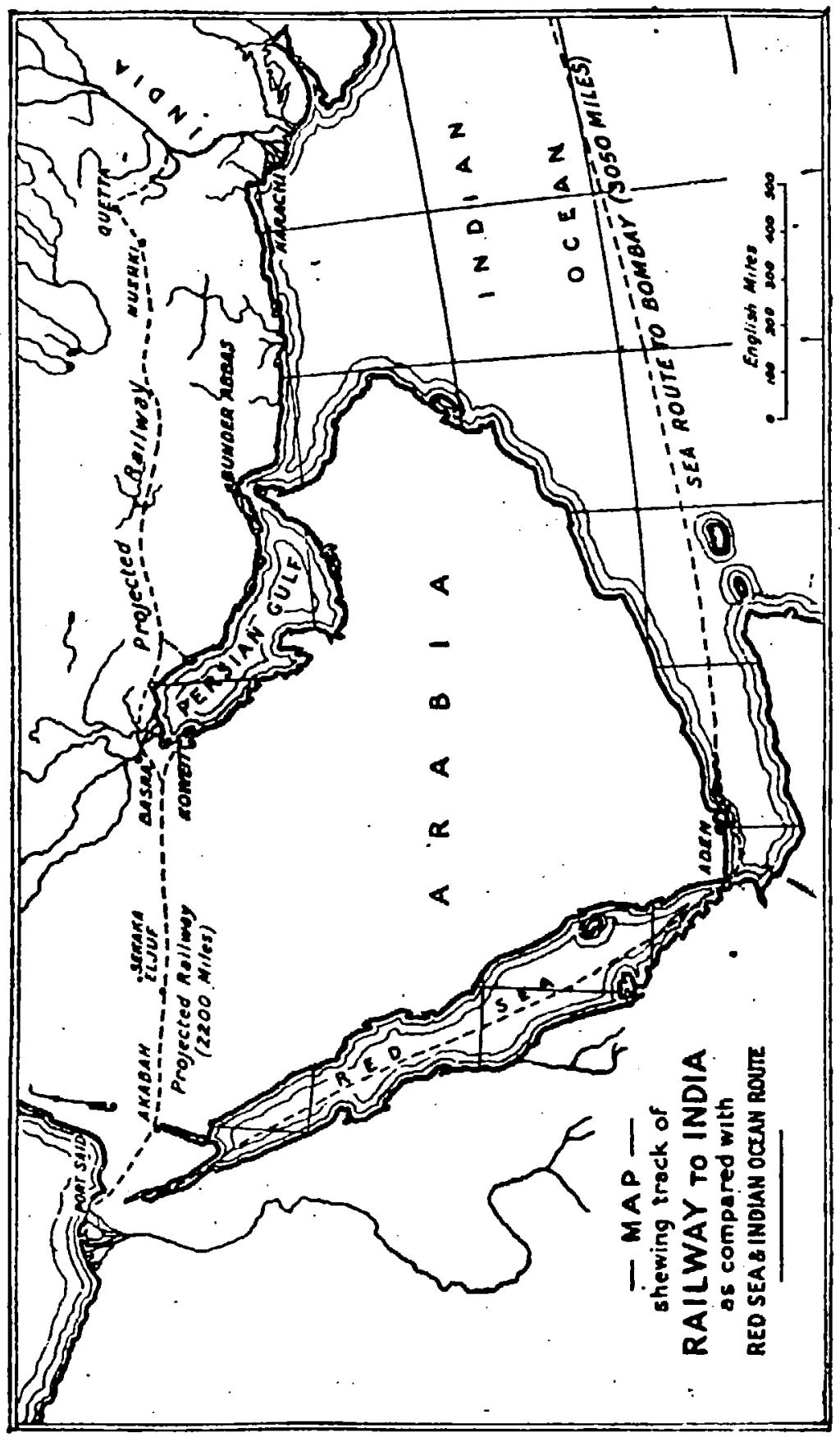




\section{DISCUSSION.}

Captain Rason, R.N.: I am surc we have listened to a very interesting lecture and one which will closcly concern the future of the Empire, the future of all of us in England and of all those in our Colonies. But in this lecture $\mathrm{Mr}$. Black has left out a few facts, possibly not having time to state them, as to the other means of reaching. India by other routes. I have been kooking them up, and it seems to me rather as if this fine, inchuding its connections with India, would be another proof of the old proverb that "The longest way round is the shortest way home." Perhaps before I have finished the ten minutes which are allowed me in which to speak, I may show you that this saying is absolutely true.

\section{Althrnativi Routrs to India.}

The shortest way, as we know, from one place to another, is on the arc of a great circle, at any rate, sailors know it. Now, the nearest route on the arc of a great circle between England and India, is through Russia, along the Baltic to St. Petersburg, from St. Petersburg to Moscow, from Moscow to Orenburg, thence to Samarkhand, and on to Peshawar. That route is 1,200 miles shorter than Mr. Black's route, but the trains and the steamers are so slow that it takes a long time to do the journey. A shorter route is from London via Berlin to Moscox, from Moscow to Orenburg, from Orenburg to Samarkhand, and from Samarkhand to Peshawar; but it takes ten days to reach Samarkhand, up to which point the railway has been constructed, and I suppose that, if the railway were pushed on to Peshawar, it would take an additional day, making eleven days in all. This route was really proposed in 1869 , but India was, at that time, very much afraid of Russia, and so the project dropped through. I am afraid it is rather out of date to-day and would prove to be too slow.

The next route from London is via Berlin, Cracow, Lemberg, Bucharcst, down to the Turkish frontier via Constanzia, and so to Constantinople. There is one objection to this route, namely, there are very many changes; one changes at Harwich, at Flushing, at Berlin, on the Austrian frontier, on the Roumanian frontier, again at Constanzia, and again at Constantinople, for the Baghdad Railway, and by the time the passenger gets to Basra, which is where I suppose Mr. Black's route and that route would cross, the passenger would have made eight changes, each of which occupies a good deal of time.

Then there is a route through France, vif Paris to Marseilles, and then by 20-knot steamers to Port Said, and in that way one might get to Port Said in 4 days 8 hours from London. Starting from Plymouth, if we put on that route two vessels like the "Mauretania "to run once a week, we should get from Plymouth to Port Said in lour days sixteen hours. Then, allowing two hours for a change, and assuming that on the journey by Mr. Black's route from Port Said to Basra (900 miles), the trains ran at about 40 miles an hour-or seven miles an hour less than the express trains from London to Inverness-we should get to Basra in 5 days 18 hours from Plymouth. The Germans have been very lucky, they have got the arc of the great circle from London through Berlin and Bucharest to Basra. If we take the Baghdad Railway as being 2,000 miles long, a passenger could get to Basra in 6 days 8 hours. By Mr. Black's line-assuming that the journey from Plymouth was done in the "Mauretania " or "Lusitania," and counting to miles an hour 
on the railway-we would be able to get to Basra 12 hours before the passengers by the other routc; that is to say, the longest way round would would prove to be the shortest way home.

Of course, the route by Russia is out of it. Mr. Black has already told us he is going to do it by his route in 8 days. We must remember that ten years ago we had the blue riband of the Atlantic taken from us, much to the dislike of the British people, and that a subsidy was given to the Cunard line to build two steamcrs, the "Mauretania" and the "Lusitania," and in that way we got the blue riband back, and we have it now. The other day $I$ saw in the paper that the "Mauretania" left New York 24 hours after one of the fastest of the German steamers. The German steamer went to Cherbourg and landed her passengers for Paris. The "Maurctania" landed her passengers at Fishguard and they had to travel by Reading and Dover to Paris, but although they had started 24 hours behind the passengers by the German steamer, they reached Paris only six hours behind. If we can do that in the Atlantic I think we might do the same in the Mediterranean. At any rate, we shall probably see a good deal of emulation in speed, when the Baghdad Railway is completed, and Mr. Black's railway is made, to see who is going to get there first. If Mr. Black can get the British public to take up his railway in the same way that they took up the question of the "blue riband of the Atlantic," there is no doubt we shall have practical proof in the time to come that the longest way round is proved to be the shortest way home.

Lient.-Colonel A. C. Yate: I have felt myself the difficulty of having to advocate, a possible railway line between Europe and India; for only last Fcbruary. I studied to the best of my ability and laid before the Central Asian Society the possibilitics of the Trans-Persian Railway. I do not know how many of us, when we take up a thing keenly, fully realise how very apt we are to look at things. "couleur de rose," and I am strongly impressed with the fact that Mr. Black occasionally looks at his railway very much as it is represented on the map on the wall, "couleur de rose." lle passes over in a very few words the great engineering difficulties in the valley. of the Tigris and Euphrates, the difficulties of both crossing that valley and of getting up to the Persian Plateau. Indeed, I was rather struck by the fact that in indicating the line he would take he went up to Yezd, came down to Shiraz, and turned up again to Kerman, an extremely zigzag route which, I am perfectly certain, no. Egypto-Indian railway would follow.

\section{The Qurstion of the Indian Rei.irfs.}

Then, when he talks of carrying 34,000 British soldiers regularly (I presume, the annual reliẹfs) betacen India and the Mediterranean, 1 am convinced, in my own opinion, that the British and Indian Governments will not want to carry soldicrs by rail, that method being more expensive than conveyance by water. If you take the line from the Indus Valley by land to Port. Said, and the line from Bombay up the Red Sea to the same point, the difference in distance is not great, and there is no change from rail to ship, or vice versa. It is true that they move the troops in the cold weather, but I imagine the British Tommy would get.infinitely more fatigued with the long journey from the Indus Valley to the Mediterranean by train than he would by a steamer journey up the Red Sea. These are little things, I confess, in what is a great policy. 
Had not the gentleman who has just spoken anticipated me, I had thought of saying more in connection with alternative routes. He has already extremely well sketched two of them, the Russian route which goes through Orenburg and on to the Northern Frontier of Afghanistan, ready, on the Amir's permission being given, to move on into India, and the Baghdad Railway. Then there is the Trans-Persian, which is at present comparatively in the air, and I think we may as well leave it there, time being short.

\section{WOULD THE RaIL WAY PAY?}

As far as my knowledgre goes, the line of route from Port Said to the N.W. end of the Persian Gulf traverses territory from which little can be expected in the way of commerce; but it connects lands with a great past and, probably, a great future. The ancient monarchies of the Tigris and Euphrates Valleys and.Persia had close communication with Egypt; so much so that Persia under Cambyses conquered Egypt and the Cyrenaica. If that close communication is restorod, if Mesopotamia becomes a very prosperous country, if Egypt under our rule, and Northern Africa under the control of various European Poxers, attain a degree of prosperity which they have not for centuries, if ever, known, we may surely argue from that that commercial relations will be reopened between Egypt and North Africa on the one hand, and Mesopotamia and Persia on the other. That I think is a solid argument in favour of Mr. Black's contention that a railway across Northern Arabia might be possible, and might pay. I am more convinced of that than I am of the necessity of the railway for the purposes of British policy ; for I look upon it as an extremely difficult thing for the British Government so to settle matters at this juncture with the Turkish Government and with the Arab tribes, that a railway can be securely and satisfactorily constructed from Port Said to Basra by British capital, and maintained there under British control. Mr. Black has attempted an analogy between what Russia does in her own Siberian territory, and what we might possibly do in other people's territory, an absolutely fallacious analogy. 1 am certain that an Arabo-Turkish concession for a railway from the Syrian, coast to the Shat-al-arab would bristle with incalculable diffculties.

It remains for me to say a few words about the section of Mr. Black's proposed line which connects Mesopotamia with the Indian frontier. I doubt the utility of this railway to the Anglo-Persian Oil Company. That Company has, I understand, already laid its pipe-line towards the head of the Persian Gulf. Oil finds its way into tank-ships, and so to its destination. less expensively than into and by tank-trucks. Angla-Persian Oil railed will not compete with Baku oil shipped either in the Mediterranean or anywhere else.

\section{The Situation of the TrRminus.}

Coming to the question of making Nushki the terminus, that is a point which I had seriously to consider in regard to my Trans-Persian Railway. Not only. I, but a good many other specialists, thought that either Karachi or some point between Karachi and Sukkur should be the terminus. I noticed that when Lord Hardinge went down to Karachi a few months ago, the Karachi Chamber of Commerce particularly drew his attention to the claim Karachi had to be the terminus of such a 
railway, and his Excellency's reply was that the Government of India was giving the whole question their very serious consideration. Now, when the Government of India gives a thing very serious consideration, I think we may conclude there are strong arguments in its favour: I do not regard Nushki as at all a good terminus. If you go to Nushki, you must go up to Quetta, and again down to Sibi-5,000 feet up and down for nothing. Or, you must cross the mountains from Nushki 10 the Gomal Pass and so reach the plains of the Punjab. There are tro bridges over the Indus, one at Sukkur and the other at Kotri; and both these bridges connect Baluchistan and the West with the centre of India by a number of important railways. If possible, we should, I think, seek for the terminus of our railway, be it Trans-Persian, or EgyptoIndian, at, or near Kotri, with a branch, perhaps, from Panjgur or Las Bela to Karachi. There is not a shador of doubt in my own mind that the colours in which Mr. Black has sketched the difficulties, or the absence of difficulties, in constructing a line across Persia and Baluchistan are unwarrantably faint. The difficulties are serious. Still, for the rcasons I have mentioned, viz., to facilitate the relations betueen Egypt and Mesopotamia, to which peace and prosperity will give rise, I think that amongst those railways of the future which will undoubtedly connect West with East-and the time will come when they will not only reach India, but will stretch right across to the Pacific-it is possible that Mr. Black's railway, or one very like it, will be included. The passenger from the Cape will, doubtless, in course of time reach without break of gauge Vladivostok on the Pacific or Jakutsk on the Lena.

Sir J. D. Rees, K.C.I.E.: I should like to ask, as Mr. Black is going to reply upon this debate, whether, supposing the Baghdad Railway is hid down as far as Baghdad, he regards it as a serious proposition that there should be another line short circuiting it from the Egyptian Delta to the head of the Persian Gulf. Already we know that the concession for the Baghdad Railway had been amended so as to provide for a branch to Alexandretta, affording railway communication from Alexandretta to the head of the Gulf. There you have a project which has already rcached a considerable stage towards fruition.

\section{The Coymercial. Prospects of the Proposed Rail.way.}

How does Mr. Black regard it possible as a commercial proposition that there should be another line going straight across this desert part of Arabia? The project in this aspect seems to have been conceived without any regard to existing facts. If the railway is to be regarded solely as a strategical line it would be sufficient to say that under no circumstances would British troops require that method of approach to India. The sea, of course, is far safer, and not so very much longer. In point of fact, except for the mails, I do not myself see in what way a railway approach to India would be of any benefit to this country or to India itself. It is well known that competition has only to come into play to accelerate very much the time in which the $P$. $O$. can take mails to India, and that the contract time admits of great acceleration. Colonel Yate has spoken of Mesopotamia and its future prospects: It was thought likely that Mesopotamia woukd again become a great granary, but I believe that prospect is already impaired if not destrojed. The great irrigation engineer who had the matter in hand, I believe, has left, and certainly the conditions of the Turkish Empire do not seem VOL. LV. 
likely, within any given period, to admit of any progress in the arts of peace and irrigation. I cannot see, therefore, what commercial prospects there arc of a satisfactory character even for a prolongation of the Bagikdad Railway from Baghdad to the Gulf; and how there could be any prospects for this other, and presumably competing line, commercially. I must say, I altogether fail to understand.

\section{The Extrission of the Railway throvgh Persia.}

As regards the line from the head of the Persian Gulf towards the Indus, that is common to all schemes except the one that is to go through the North to Afghanistan. No doubt it would be extrericly advantageous to this country that some railway should be projected that way, even if it never got beyond the state of a project, because under the Anglo-Russian Convention the greater part of its course would run through neutral territory, and it is extrenely desirable that this territory should be occupied with a scheme or project that will keep out other poople. Unless we have some scheme it is not at all improbable that somebody else will come in with one and run right athwart the trade lines we have developed, and ought to continue to develop and use. Had the Anglo-Russian Convention really been an Anglo-Persian Convention and made with reference to our position in that country only, it would have been extremely unfair that this region should have been neutral. As it is neutral, and as I believe, under the existing. atrangements, loth lowers, Russia and England, are pledged not to compete with one another in neutral ground, it is excedingly desirable on every score that a survey or a project or something of a diplomatic, if not of an engineering character, should be set on foot, that we may hold the field for this portion of the line. I venture to make these few remarks not to discourage Mr. Black, because I think it is a very goorl thing that he does, as Colonel Yate said, sec things "couleur de -rose," and not "en noir"-I congratulate him on that-but I have fot it necessary to make these fow remarks because I cannot quite the practicability of his scheme in view of the considerations I have nuentionod.

Captain Chas. Slack said he thought it was the opinion of the public generally that we ought to have a more direct line of communication with India.

The quickest overland route to the East at present was by the Orient Express, via Constantinople. That route continued from Constantinople through Asia Minor, and the line was now completed to Bulgurlu; when it was extended to Damascus and Jerusalem it would open up a very important route for visitors to the East to consider. Then it might go on and join with Mr. Black's surgested route across Arabia. "When considering the line from Port Snid he thought it might just as wall have been carried further north, so as to avoid the tribal considerations. When the line reached Koweit he did not see why it should not run through Basra and along the coast to Bunder Abbas.

There had been very many lines put forward. He did not think relying on military or political considerations was of ruch great importance as compared with what the travelling public of the future might consider the best route to India. Military officers would probably use the line coming through Constantinople. Although they might lose a little in the zirr-zag lines of railway through $\Lambda$ sia Minor, they would see the countries through which they passed. Travetlers were always anxious to sce new countries. 
He hoped that Mr. 13lack might at sonic future time favour them with another paper on the subject, giving them his further and extended views.

Mr. C. E. D. Black, in reply, said : Coloncl Yate made some remarks about the conveyance of troops. I did not mean to imply in my paper that it was part of the scheme that the railway should be available for the conveyance of all troops travelling between India and England. I only meant to remark that there is a very large exchange in connection with the ordinary reliefs between the two countries, and that, in case of necessity, troops might be conveyed with great rapidity. I daresay it is perfectly true that "Tommy" would prefer to go by sea. For nine years that method might possibly be preferred, but then some sudklen emergency night arise which would make it extremely necessary for troops to be conveyed more quiclily, and in that case we should derive such benefit from the rapid conveyance of troops in the tenth ycar as would amply compensate for the railway having been a non-productive line-as far as troops were concerned-for the preceding nine years.

\section{The Position of the Triminus.}

One speaker has said that Karachi would make a better terminus than Nushki. That is a point of detail. I do not pin my faith un Nushki at all. I think Karachi under certain circumstances might make a very admirable terminus. Before this railway reaches the Indian frontier a proper survey would establish beyond doubt which was the most convenient terminus to be fixed upon. After all there is not such an enormous range of country between Karachi and Nushki, and if Karachi fulfilled the purpose better it could quite well be chosen.

\section{Tirt Baghdan RaILWay.}

Sir John Rees said a good deal about the Baghdad Railway, but I could not follow him very clearly in his arguments. I cannol understand why this railway should interfere with the Baghdad Railway, or why it should be rendered unnecessary because of the existence of the Baghdad Railway. The l3aghdad Railway is not completed; it only goes as far as a point in the N.E. angle of the Mediterranean Sea; and we can hardly look upon it as a serious proposition until it matures more than it has done. In any case my railway would exploit a very different region, and is also an endeavour to unite Egypt with India, and that, of course. is quite outside the function of any enterprise like the Baghdad Railway. There are a great many points of detail which speakers have insisted upon rhich, of course, might be open to discussion; but as far as the main proposition is concerned, I am content, speaking for myself, that the meeting is not inimical to it.

The Chairman: I am sure we are all very much obliged to Mr. Black for his lecture.

It has been said that he has viewed his scheme and set it before us " couleur de rose"; but after all that is the foundation of the entliusiasm which makes things work. Looking at matters "en noir" means depression and inaction.

As to the merits of the scheme, my own feeling is that geographical difficultics, such as those montioned by Coknel Yate, are of comparatively small importance. Geographical difficulties are being overcome all over the world, by Russia and by us and by cverybody else. In the future the ovcrcoming of all natural obstacles will be accelerated. 
It seems to me that every project of this kind has to be looked at Irom tro points of view, one from the strategical and the other the commercial. I do not feel that I am able to give any opinion worth having as to whether this project is a sound one from the commercial point of view. That requires a great deal more consideration before a confident opinion can be given one way or the other. But I should like to say one word, after what we have heard from Sir John Rees, Colonel Yate, and others, with regard to the strategical aspect of the proposed railway. I daresay I may be quite wrong, but my own feeling is that as a strategicitl project it is a very doubtful one. The railway would not be an all-red route. Whatever influence we may have over it, however much we may have to do with working it, the line will he, as Colonel Yate pointed out, through territories which do not belong to us; and it seems to me that the idea of using, as a strategical route, a line of railway which runs through foreign territory for hundreds or thousands of miles, is unsound. It appears to me that the only. real foundation for a strategical route is armed power; and that the only sphere in which we can reasonably hope to have preponderating armed power is the sea. That is the sound strategical line to India-our old line of the sea by which we took India.

Before I sit down I wish to ask you all to join in a hearty vote of thanks to Mr. Black, whose lecture has been very interesting and has shown great labour and care.

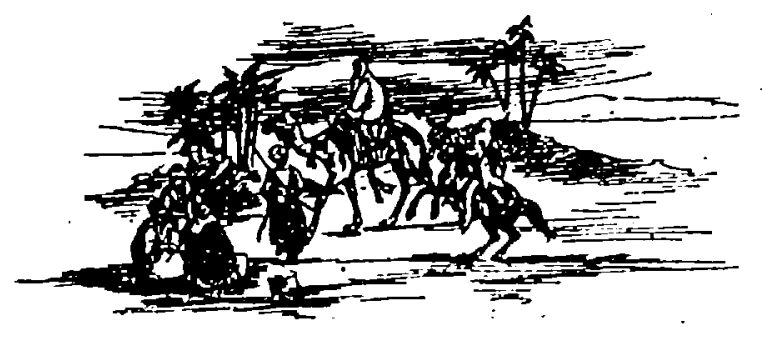

